\title{
PEMBERIAN PAKAN ALAMI YANG BERBEDA TERHADAP PERTUMBUHAN DAN KELANGSUNGAN HIDUP LARVA IKAN NILEM (Osteochilus hasseltii)
}

\section{DIFFERENT NATURAL FEEDING TO THE GROWTH AND SURVIVAL OF LARVAE NILEM FISH (Osteochilus hasseltii)}

\author{
Sufal Diansyah $^{1 *}$, Yuli Erina ${ }^{2}$, Mika Raudhatul Jannah ${ }^{2}$ \\ ${ }^{1}$ Jurusan Akuakultur, Fakultas Perikanan dan Ilmu Kelautan, Universitas Teuku Umar, Aceh Barat \\ ${ }^{2}$ Jurusan Perikanan, Fakultas Perikanan dan Ilmu Kelautan, Universitas Teuku Umar, Aceh Barat \\ *Korespondensi : sufaldiansyah@utu.ac.id
}

\begin{abstract}
ABSTRAK
Larva ikan nilem (Osteochilus hasseltii) membutuhkan jenis pakan alami yang tepat untuk menunjang kelangsungan hidup dan pertumbuhannya. Penelitian ini bertujuan untuk menganalisis jenis pakan alami yang memberi kinerja produksi terbaik terhadap larva ikan nilem. Penelitian ini menggunakan larva ikan nilem berumur 10 hari. Rancangan percobaan yang digunakan adalah rancangan acak lengkap (RAL) dengan empat perlakuan jenis pakan berbeda dengan tiga ulangan. Jenis pakan yang digunakan adalah kuning telur ayam sebagai kontrol (P0), tubifex beku (P1), moina (P2), dan dapnia (P3). Hasil penelitian menunjukkan bahwa pemberian jenis pakan alami berbeda berpengaruh nyata terhadap kinerja produksi larva ikan nilem. Derajat kelangsungan hidup tertinggi $(80 \%)$ terdapat pada P2 dan terendah $(69 \%)$ terdapat pada P1. Laju pertumbuhan berat mutlak tertinggi $(2,96)$ terdapat pada P2 dan terendah $(2,58)$ terdapat pada P1. Laju pertumbuhan panjang mutlak tertinggi $(3,4)$ terdapat pada $\mathrm{P} 2$ dan terendah $(2,7)$ terdapat pada P1.
\end{abstract}

Kata kunci :Larva, Osteochilus hasseltii, pakan alami, pertumbuhan.

\begin{abstract}
The larvae of nilem fish (Osteochilus hasseltii) need the right kind of natural feed to support their survival and growth. The aims of this study were to analyze the type of natural feed that gives the best production performance of larvae of nilem fish. This study used 10-day nilem fish larvae. The experimental design used was completely randomized design with four different feed type treatments with three replications. Type of feed used was chicken egg yolk as control (P0), frozen tubifex $(\mathrm{P} 1)$, moina $(\mathrm{P} 2)$, and dapnia $(\mathrm{P} 3)$. The results showed that all treatment different feed give significant effect on the production performance. The highest survival rate $(80 \%)$ is found at P2 and the lowest $(69 \%)$ is in P1. The highest growth rate $(2,96)$ is found at P2 and the lowest $(2,58)$ is in P1. The highest long growth rate $(3,4)$ is found at P2 and the lowest $(2,7)$ is in P1.
\end{abstract}

Keyword : Larvae, Osteochilus hasseltii, natural feed, growth.

*Fakultas Perikanan dan Ilmu Kelautan, Universitas Teuku Umar

Korespondensi : Jurusan Akuakultur, Fakultas Perikanan dan Ilmu Kelautan, Universitas Teuku Umar, Kampus UTU Meulaboh, Alue Peunyareng 23615, Telp: +62 85288323477, email: sufaldiansyah@utu.ac.id 


\section{PENDAHULUAN}

Ikan nilem (Osteochilus hasseltii) merupakan komoditas asli Indonesia yang sudah dibudidayakan sejak lama oleh masyarakat. Ikan nilem sangat potensial untuk dikembangkan menjadi produk unggulan perikanan budidaya. Budidaya ikan nilem ini menguntungkan dilihat dari sisi ekonomi, kelestarian lingkungan, dan produksi budidaya. Keberhasilan usaha budidaya pada hakekatnya ditentukan oleh tingkat produksi tinggi yang dipengaruhi oleh laju pertumbuhan dan kelangsungan hidup yang tinggi. Laju pertumbuhan dan kelangsungan hidup dipengaruhi antara lain oleh ketersediaan pakan, kualitas lingkungan, hama dan penyakit.

Tingginya tingkat kematian benih menunjukkan rendahnya tingkat kelangsungan hidup benih. Keberhasilan budidaya ikan pada suatu unit pembenihan tidak hanya ditentukan oleh teknik budidaya tetapi juga oleh produksi dan penggunaan pakan alami sebagai pakan untuk perkembangan larva (Sorgeloos dan Lavens, 1996). Kelangsungan hidup sangat dipengaruhi oleh ketersediaan pakan sebagai sumber energi untuk pertumbuhan. Salah satu usaha untuk mengatasi rendahnya kelangsungan hidup dan menunjang pertumbuhan pada stadia larva, dilakukan dengan pemberian pakan yang tepat baik ukuran, jumlah, dan kandungan gizi dari pakan tersebut.

Syarat pakan yang baik adalah mempunyai nilai gizi yang tinggi, mudah diperoleh, mudah diolah, mudah dicerna, harga relatif murah, tidak mengandung racun. Jenis pakan disesuaikan dengan bukaan mulut ikan, dimana semakin kecil bukaan mulut ikan maka semakin kecil ukuran pakan yang diberikan, dan juga disesuaikan dengan umur ikan.

Kebiasaan makanan ikan nilem (Osteochilus hasseltii) merupakan ikan pemakan fitoplankton, zooplankton dan detritus pakan alami sangat diperlukan dalam budidaya ikan dan pembenihan, karena akan menunjang kelangsungan hidup benih ikan. Pada saat embrio baru menetas larva masih memiliki cadangan makanan berupa kuning telur yang dapat dimanfaatkan oleh larva selama beberapa hari. Setelah itu larva ikan membutuhkan pakan dari luar yang berupa pakan alami. Pemberian pakan yang tidak sesuai dengan bukaan mulut larva akan mengakibatkan larva tidak mampu mengkonsumsi pakan tersebut sehingga dapat menyebabkan kematian. Disamping itu pakan alami yang tidak termanfaatkan dapat menyebabkan tingginya kadar amoniak, yang mengakibatkan kualitas air media menurun (Rabiati, 2014).

Dalam usaha pembenihan tahap awal pemberian pakan harus sangat diperhatikan. Kesalahan dalam pemberian pakan yang berupa ukuran pakan yang tidak sesuai dengan bukaan mulut dan jenis pakan merupakan kesalahan fatal dalam kegiatan pemeliharaan larva, Untuk itu perlu diperhatikan bukaan mulut larva sehingga pakan alami yang diberikan dapat dikonsumsi oleh larva. Oleh karena itu, peneliti tertarik melakukan penelitian dengan judul "Pengaruh Pemberian Pakan Alami Yang Berbeda (Tubifex, Dapnia, dan Moina) Terhadap Pertumbuhan Dan Kelangsungan hidup Larva Ikan Nilem (Osteochilus hasseltii) "

\section{METODE PENELITIAN}

\section{Rancangan percobaan}

Penelitian ini dilakukan dengan metode eksperimental. Rancangan percobaan yang digunakan adalah rancangan acak lengkapdengan empat perlakuan pemberian jenis pakan berbeda dan masing-masing perlakuan diulang sebanyak tiga kali.Jenis pakan yang digunakan adalah kuning telur ayam sebagai kontrol (P0), tubifex beku (P1), moina $(\mathrm{P} 2)$, dan dapnia $(\mathrm{P} 3)$.

\section{Prosedur penelitian}

Wadah yang digunakan berupa toples dengan kapasitas 20 liter. Sebelum dilakukan penelitian, wadah terlebih dahulu dibersihkan, selanjutnya dimasukkan air kedalam wadah setinggi $30 \mathrm{~cm} . I k a n$ uji yang digunakan adalah larva ikan nilem ukuran 10 hari dengan berat 0.08 gram dan panjang $0.6 \mathrm{~cm}$ sebagai ikan uji, dalam setiap wadah perlakuan digunakan 25 ekor larva ikan nilem. Larva ikan nilem berasal dari Balai Benih Ikan (BBI) Krueng Bate Kecamatan Blang Pidie Kabupaten Aceh Barat Daya.Pakan uji yang digunakan dalam penelitian ini adalah tubifex beku, moina dan dapnia. Pakan uji tubifex, moina dan dapnia didapatkan dari hasil kultur. Pemberian pakan uji pada tiap perlakuan dilakukan dengan frekuensi $3 \mathrm{x}$ 
sehari secara adlibitum. Dengan waktu pemberian pukul 08.30, pukul 12.30 dan pukul 18.00 WIB.

\section{Parameter Uji}

Parameter yang diuji selama penelitian meliputi parameter biologi yang terdiri atas derajat kelangsungan hidup, laju pertumbuhan mutlak dan rasio konversi pakan, serta parameter kualitas air yang meliputi suhu dan pH. Sampling bobot dilakukan setiap sepuluh hari dan kelangsungan hidup dihitung pada akhir penelitian. Pengukuran suhu dan $\mathrm{pH}$ dilakukan setiap hari pada pagi dan sore hari.

\section{Derajat kelangsungan hidup}

Derajat kelangsungan hidup (SR) adalah perbandingan jumlah ikan yang hidup sampai akhir pemeliharaan dengan jumlah ikan pada awal pemeliharaan, yang dihitung menggunakan rumus dari Goddard (1996) yaitu:

$$
S R=\left(\frac{N_{t}}{N_{0}}\right) \times 100 \%
$$

Keterangan:

$\mathrm{SR}=$ Derajat kelangsungan hidup (\%)

$\mathrm{N}_{\mathrm{t}}=$ Jumlah ikan hidup pada akhir pemeliharaan (ekor)

$\mathrm{N}_{\mathrm{o}}=$ Jumlah ikan pada awal pemeliharaan (ekor)

\section{Laju pertumbuhan berat mutlak}

Laju pertumbuhan mutlak adalah perubahan bobot rata-rata individu dari awal sampai akhir pemeliharaan. Pertumbuhan bobot mutlak dihitung dengan menggunakan rumus dari Goddard (1996):

Keterangan:

$$
\mathrm{GR}=\frac{W t-W o}{t}
$$

$$
\begin{aligned}
\mathrm{GR}= & \begin{array}{l}
\text { Laju pertumbuhan bobot mutlak } \\
\text { (gram/ekor/hari) }
\end{array} \\
\mathrm{W}_{\mathrm{t}}= & \begin{array}{l}
\text { Bobot rata-rata pada akhir } \\
\text { pemeliharaan (gram) }
\end{array} \\
\mathrm{W}_{\mathrm{o}}= & \begin{array}{l}
\text { Bobot rata-rata pada awal } \\
\text { pemeliharaan (gram) }
\end{array} \\
\mathrm{t} \quad= & \text { Periode pemeliharaan (hari) }
\end{aligned}
$$

\section{Laju pertumbuhan panjang mutlak}

Pertumbuhan panjang mutlak dapat dihitung dengan menggunakan rumus Goddard (1996).

$$
L M=\frac{L_{t}-L_{O}}{t}
$$

Keterangan:

Keterangan:

$$
\begin{array}{ll}
\mathrm{LM} & =\text { Pertumbuhan panjang mutlak }(\mathrm{cm}) \\
\mathrm{L}_{\mathrm{t}} & =\text { Panjang akhir }(\mathrm{cm}) \\
\mathrm{L}_{\mathrm{o}} & =\text { Panjang awal }(\mathrm{cm}) \\
\mathrm{T} & =\text { Periodepemeliharaan (hari) }
\end{array}
$$

Penelitian ini dilaksanakan pada Maret sampai dengan Desember 2016 bertempat di Laboratorium Hayati MIPA Unsyiah, di Laboratotium Ilmu dan Teknologi Pengolahan Susu Unsyiah di, Hachery Fakultas Perikanan UTU, Meulaboh.

\section{HASIL DAN PEMBAHASAN}

Derajat kelangsungan hidup

Derajat kelangsungan hidup rata-rata larva ikan nilem yang dipelihara dengan pemberian jenis pakan yang berbedaberturutturut sebesar 73\% (P0), 69\% (P1), 80\% (P2), dan 75\% (P3) (Tabel 1). Hasil analisis statistik perbedaan jenis pakan larva ikan nilem menunjukkan adanya pengaruh nyata terhadap derajat kelangsungan hidup $(\mathrm{P}<0,05)$.

Laju pertumbuhan berat mutlak

Laju pertumbuhan berat mutlak setiap perlakuan menunjukkan adanya perbedaan yang nyata $(\mathrm{P}<0,05)$. Laju pertumbuhan berat mutlak larva ikan nilem yang dipelihara dengan perlakuan jenis pakan alami berbeda berturut-turut sebesar 0,087 (P0), 0,083 (P1), 0,096 (P2), dan 0,092 (P3) (Tabel 1).

Laju pertumbuhan panjang mutlak

Laju pertumbuhan panjang mutlaklarva ikan nilem yang dipelihara dengan pemberian jenis pakan yang berbedaberturut-turut sebesar0,07(P0), 0,06(P1), 0,09(P0), 0,08(P0) (Tabel 1). Hasil analisis statistik perbedaan jenis pakan larva ikan nilem menunjukkan adanya pengaruh nyata terhadap laju pertumbuhan panjang mutlak $(\mathrm{P}<0,05)$. 
Tabel 1 Parameter produksi larva ikan nilem yang dipelihara selama 30 hari pada pemberian jenis pakan alami berbeda.

\begin{tabular}{lcccc}
\hline \multirow{2}{*}{ Parameter Produksi } & \multicolumn{4}{c}{ Perlakuan } \\
\cline { 2 - 5 } & $\mathrm{P} 0$ & $\mathrm{P} 1$ & $\mathrm{P} 2$ & $\mathrm{P} 3$ \\
\hline $\begin{array}{l}\text { Derajat kelangsungan hidup (\%) } \\
\begin{array}{l}\text { Laju pertumbuhan berat mutlak } \\
\text { g/ekor/hari) }\end{array}\end{array}$ & 73,3 & 69,3 & 80,0 & 74,7 \\
$\begin{array}{l}\text { Laju pertumbuhan panjang mutlak } \\
\text { (cm/ekor/hari) }\end{array}$ & 0,087 & 0,083 & 0,096 & 0,092 \\
\hline
\end{tabular}

Pembahasan

Persentase kelangsungan hidup adalah perbandingan jumlah ikan hidup pada akhir penelitian dengan jumlah ikan yang hidup pada awal penelitian pada satu periode dalam satu populasi (Mulyadi, 2010). Perbedaan tingkat kematian pada setiap perlakuan disebabkan oleh perbedaan jenis pakan yang diberikan. Semakin tinggi kadar protein dalam pakan maka akan semakin besar kemungkinan sisa dari pakan tersebut penyebab amoniak.Selain itu, rendahnya rerata persentase kelangsungan hidup larva ikan nilem pada penelitian diduga karena larva ikan nilem belum sepenuhnya mampu memakan pakan alami yang diberikan. Apabila pakan yang dikonsumsi oleh larva ikan nilem sedikit jumlahnya maka energi yang dihasilkan tidak optimal baik untuk pertumbuhan maupun untuk pemeliharaan. Sehingga persentase mortalitas larva ikan nilem pada penelitian ini masih cukup tinggi.

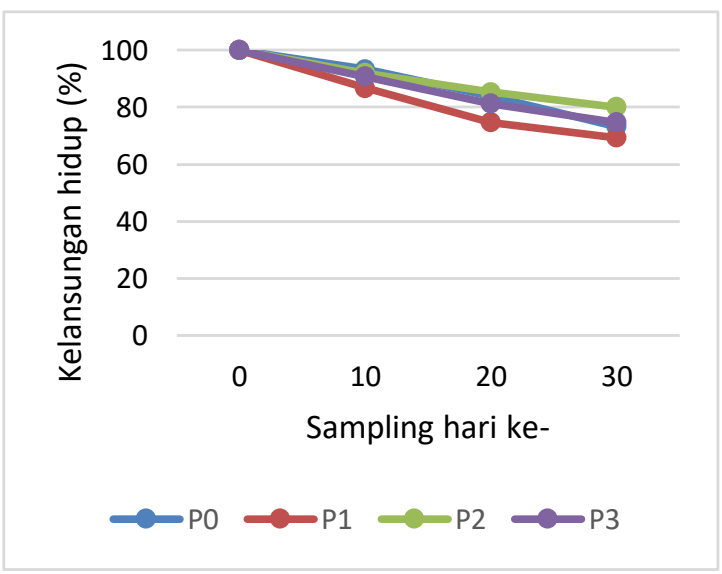

Gambar 1. Kelangsungan hidup ikan nilem selama penelitian

Berdasarkan Tabel 1 secara spesifik dapat dilihat bahwa adanya perbedaan pada setiap perlakuan, hal ini telah menunjukkan bahwa pemberian pakan kuning telur sebagai kontrol, pemberian pakan tubifex beku, moina dan dapnia memiliki pengaruh terhadap pertumbuhan larva ikan nilem. Tingginya nilai pertumbuhan pada perlakuan P2 dikarenakan nilai protein pada pakan tersebut dapat memenuhi kebutuhan protein larva ikan nilem.Selain itu, moina yang hidup dan masih bergerak menyebabkan pakan akan terasa lebih menarik bagi ikan hal ini terlihat dari respon ikan yang diberikan pakan alami moina yang lebih tinggi dibandingkan dengan respon ikan uji lainnya.

Gambar 2. Laju pertumbuhan mutlak

Respon ikan yang baik terhadap pakan membuat nutrisi yang terdapat dalam pakan akan dapat masuk kedalam tubuh ikan melalui

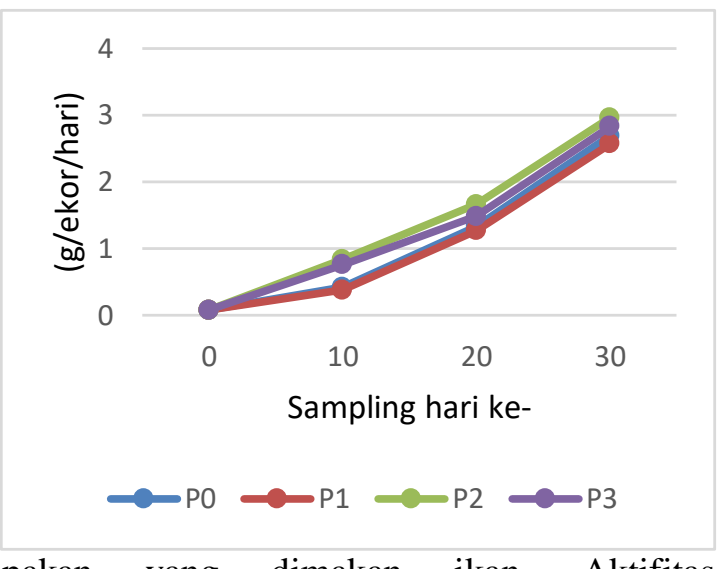

pakan yang dimakan ikan. Aktifitas penyerapan nutrisi terutama protein di dalam tubuh ikan dapat memacu pertumbuhan ikan dengan cara mengambil protein dari pakan dan mengubahnya menjadi energi untuk bertumbuh dikarenakan pertumbuhan terjadi apabila ada kelebihan energi setelah energi yang digunakan untuk pemeliharaan tubuh, metabolisme basal, dan aktivitas.

Selain itu kecernaan pakan berkorelasi positif dengan protein efisiensi rasio dan pertumbuhan ikan, dimana semakin rendah kecernaan pakannya maka semakin rendah pula protein efisiensi rasio dan semakin rendah juga pertumbuhannya. Kecernaan 
protein dipengaruhi oleh kandungan protein yang berbeda dan kualitas asam amino pada sumber pakan (Lestari, 2001). Menurut Triwidiyastuti et al. (2000), pertumbuhan merupakan perubahan ukuran berat dan panjang ikan. Analisa pertumbuhan berat ikan digunakan untuk mengetahui pengaruh pakan yang diberikan terhadap pertumbuhan ikan. Pertumbuhan juga dipengaruhi oleh faktor pakan dan kualitas air. Perbedaan pertumbuhan ikan tersebut terutama disebabkan karena masing-masing pakan mempunyai kandungan gizi yang berbeda.

Rendahnya nilai pertumbuhan yang dihasilkan pada perlakuan P1, diduga karena kandungan nutrisi yang terdapat dalam pakan tubifex beku sudah berkurang karna adanya proses pengawetan terhadap pakan. Menurut Setiawati (2004) keseimbangan komponen asam amino dan protein dalam pakan merupakan faktor utama dalam mempengaruhi pertumbuhan dan kesehatan ikan. Diduga komponen asam amino dan protein dalam pakan yang digunakan pada penelitian ini belum sesuai dengan komponen asam amino dan protein pada tubuh ikan nilem sehingga menghasilkan rerata pertumbuhan yang sedikit. Selain itu, respon ikan terhadap pakan yang relatif kecil sehingga penyerapan protein di dalam tubuh dan mengubahnya menjadi energi untuk bertumbuh kurang optimal dikarenakan pakan yang di makan sedikit sehingga penyerapan protein yang diubah menjadi energi untuk tumbuh tidak optimal hingga mempengaruhi nilai pertumbuhan ikan. Selain itu protein dalam pakan beserta rasio energi pakan juga berpengaruh terhadap pertumbuhan dan kelangsungan hidup benih ikan.

Pertumbuhan panjang terjadi seiring dengan pertambahan berat tubuh larva ikan nilem, dari Tabel 1 menunjukkan bahwa pemberian pakan alami yang berbeda memberikan pengaruh terhadap pertumbuhan panjang mutlak larva ikan nilem pertumbuhan panjang mutlak tertinggi terdapat pada perlakuan P2 (dengan perlakuan pemberian pakan alami moina) dengan nilai laju pertumbuhan panjang mutlak mencapai 0,09 $\mathrm{cm} /$ hari, dan diikuti dengan perlakuan P3 (pemberian pakan alami dapnia) dengan nilai pertumbuhan panjang mutlak mencapai 0,08 $\mathrm{cm} /$ hari, perlakuan P0 (dengan pemberian pakan kuning telur sebagai kontrol) dengan nilai pertumbuhan panjang mutlak mencapai
0,07 $\mathrm{cm} /$ hari, dan pertumbuhan panjang mutlak terendah terdapat pada perlakuan P1 (dengan perlakuan pemberian pakan alami tubifex beku) dengan pertumbuhan panjang mutlak berkisar antara $0,06 \mathrm{~cm} /$ hari.

\section{KESIMPULAN}

Kinerja produksi terbaik selama penelitian dicapai oleh larva ikan nilem (Osteochilus hasseltii) yang diberi pakan berupa moina dan yang terendah terdapat pada pemberian pakan tubifex beku.

\section{DAFTAR PUSTAKA}

Goddard S. 1996. Feed Management in Intensive Aquaculture. Chapman and Hall. New York.

Lestari S. 2001. Pengaruh kadar ampas tahu yang difermentasikan terhadap efisiensi pakan dan pertumbuhan ikan mas (Cyprinus carpio) [Skripsi]. Bogor: Institut Pertanian Bogor.

Mulyadi MT. 2010. Pengaruh frekuensi pemberian pakan yang berbeda terhadap pertumbuhan dan kelulushidupan benih ikan selais (Ompok hypothalmus). Berkala Perikanan Terubuk. 38 (2) : 21-40.

Rabiati.2014. Pemberian pakan alami yang berbeda terhadap laju sintasan dan pertumbuhan larva ikan bujuk (Channa lucius civier) [Skripsi]. Padang: Universitas Bung Hatta.

Setiawati M. 2004. Kebutuhan nutrien pakan peningkat daya tahan tubuh ikan dalam akuakultur [Disertasi]. Bogor: Institut Pertanian Bogor.

Sorgeloos P, Lavens P. 1996. Manual on Production and Use of Life Food for Aquaculture. FAO Fisheries Technical Paper. Center University of Ghent. Belgium.

Triwidiyastuti K, Izhar N, Minsyah NI, Hermawan H. 2000. Uji Adaptasi Formulasi Pakan Ikan Ekonomis Penting. Instalasi Penelitian Dan Pengkajian Teknologi Pertanian Jambi,Badan Penelitian Dan Pengembangan Pertanian. Jambi. 